\title{
Pengembangan Buku Ajar Biokimiamodel Problem Based Learning Untuk Meningkatkan Minat Membaca dan Hasil Belajar Mahasiswa Program Studi Pendidikan Biologi IKIP Budi Utomo Malang
}

\author{
Diyah Ayu Widyaningrum \\ Program Studi Pendidikan Biologi IKIP Budi Utomo Malang \\ Jalan Citandui 46 Malang \\ e-mail: uyumuyum17@yahoo.com \\ Erfitra Rezqi Prasmala \\ Program Studi Pendidikan Biologi IKIP Budi Utomo Malang \\ Jalan Citandui 46 Malang \\ e-mail: dphitlah@yahoo.co.id
}

\begin{abstract}
Based on observations and interviews with researchers lecturer of Biochemistry at the IKIP Budi Utomo Malang. The other problem is there are no print instructional materials that accommodate the needs of students. During learning less associate professor with the problems that exist around the student so that the existing textbooks are less able to encourage students to read. The consequences of the most visible problem is the low student results on the concepts learned in the course of Biochemistry. Based on observations, researcher proposes to compile Biochemistry teaching materials by using models Problem Based Learning (PBL). This research is the development of research. The development of this textbook refers Thiagarajan development model consisting of four stages. Based on the results of the research, the results of expert validation material for textbook Biochemistry shows the average percentage of 89,3 with the criteria very good. Media expert validation results of the textbook Biochemistry shows the average percentage of 78,7 with both criteria. Results of the validation practitioners to textbook Biochemistry lecturer shows the average percentage of 95 criteria very good. Legibility on student test results overall show that the textbook Biochemistry with a percentage of 95 indicates the criteria very good. Biochemistry textbook can increase interest in reading and learning outcomes of students on test readability.
\end{abstract}

Keywords: Teaching materials, Text book, Problem Based Learning, Interest in reading, learning outcome

Berdasarkan hasil observasi peneliti dan wawancara terhadap dosen pengampu mata kuliah Biokimia di IKIP Budi Utomo Malang, diketahui bahwa perkuliahan dilaksanakan dengan metode pembelajaran presentasi dan diskusi. Masalah lain yang muncul pada proses perkuliahan adalah belum ada bahan ajar cetak yang mengakomodasi kebutuhan mahasiswa. Buku ajar yang ada kurang mampu melatih mahasiswa dalam membangun pengetahuan mereka mengenai biokimia dan kurang mampu mendorong mahasiswa untuk membaca. Pengembangan buku ajar merupakan solusi pemecahan masalah yaitu dengan melihat dari segi kebutuhan dan keuntungan buku ajar. Kurangnya buku ajar Biokimia di IKIP Budi Utomo merupakan masalah mendasar dalam meningkatkan kualitas pembelajaran Biokimia.
Pengembangan buku ajar yang tepat merupakan hal penting yang harus diperhatikan, dengan berbagai masalah di atas, peneliti mengusulkan untuk menyusun bahan ajar Biokimia dengan menggunakan model Problem Based Learning (PBL).

Pengembangan bahan ajar dengan model PBL, akan mampu membelajarkan mahasiswa untuk lebih peka terhadap lingkungan sekitar. Bahan ajar Biokimia PBL selalu memulai awal penyampaian materi dengan menampilkan berbagai masalah disekitar mahasiswa, dan mahasiswa diharapkan akan mampu mengembangan kemampuan berpikir mereka dam menyelesaikan berbagai masalah yang ada. Selama proses pemecahan masalah, mahasiswa akan melakukan kegiatan membaca secara mendalam buku ajar dan sumber-sumber lain untuk 
sangat baik (tidak perlu direvisi). Hasil uji keterbacaan pada mahasiswa secara keseluruhan menunjukkan bahwa buku ajar Biokimia dengan persentase 95 menunjukkan kriteria sangat baik (tidak perlu direvisi).

Saran perbaikan dari validator ahli materi sebagai berikut.

1. Soal evaluasi pada beberapa materi (bab 1, 3 , $4,6,8,9$, dan 10) perlu ditambah

2. Sekilas peristiwa pada beberapa materi (bab 2, 4, 5, 7, 8, dan 9) kurang menarik dan kurang detail sehingga perlu diperbaiki

Saran perbaikan dari validator ahli media sebagai berikut.

1. Proporsi gambar perlu dicermati dan disebutkan sumbernya.

2. Aktivitas yang mendorong siswa melakukan kerja kelompok dan kerja mandiri belum nampak

3. Konsistensi antara latihan soal dan kompetensi dasar perlu diperbaiki.

Saran mahasiswa antara lain:

1. Penyajian warna dan gambar perlu diperbaiki agar menarik

2. Konsistensi font yang digunakan pada buku ajar.

Hasil revisi meliputi:

1. Jumlah soal evaluasi

2. Sekilas peristiwa

3. Proporsi gambar telah sesuai dan dilengkapi sumber

4. Latihan soal dan kompetensi dasar konsisten

5. Penyajian warna dan gambar menarik

6. Font konsisten

\section{PEMBAHASAN}

Buku ajar yang dikembangkan menggunakan model Problem Based Learning. Gijselaers (1996) menyatakan bahwa PBL adalah ditandai dengan pendekatan yang berpusat pada siswa, guru sebagai fasilitator bukan penyebar,yang berfungsi sebagai stimulus awal dan kerangka kerja untuk mempelajari pembelajaran berbasis masalah. Instruktur juga berharap untuk mengembangkan kepentingan intrinsik siswa dalam materi pelajaran, menekankan belajar bukan hanya mengingat, mempromosikan tugas kelompok, dan membantu siswa menjadi pebelajar mandiri. Selain menekankan belajar dengan "melakukan", PBL menuntut siswa untuk menjadi menyadari kemanpuan meta- kognitif. Artinya, siswa harus belajar untuk menjadi sadar akan apa informasi yang mereka sudah ketahui mengenai suatu permasalahan, apa informasi yang mereka perlu tahu untuk memecahkan masalah, dan strategi yang digunakan untuk memecahkan masalah. Selain itu, PBL juga dapat mengartikulasikan pikiran seperti membantu siswa menjadi lebih efektif dalam memecahkan masalah dan mengarahkan diri sendiri.

Buku ajar yang dikembangkan menggunakan format penulisan yang dimodifikasi dari Prastowo (2012). Komponen buku ajar yang dikembangkan meliputi:

1. Sampul Luar (Depan)

\section{Sampul Belakang}

3. Kata Pengantar

4. Daftar Isi

\section{Isi Buku}

Penyajian materi pembelajaran pada setiap kegiatan sesuai dengan urutan logika berpikir peserta didik seperti yang disarankan pada tahap validasi. Materi pembe-lajaran diorganisasikan menjadi urutan yang bermakna, bahan disajikan pada bagian-bagian yang bergantung pada kedalaman materi dan tingkat kesulitannya. Uraian materi juga dilengkapi dengan ilustrasi dan gambar-gambar terkait. Hal ini didukung pendapat Sungkono (2009) yang menyatakan bahwa uraian materi harus disajikan secara naratif atau piktorial yang berfungsi untuk merangsang dan meng kondisikan tumbuhnya pengalaman belajar (learning experiences).

\section{Evaluasi}

Soal evaluasi terdiri dari soal uraian dengan item yang bervariasi pada tiap bab. Evaluasi pada buku ajar dikerjakan setelah siswa selesai mempelajari seluruh materi dalam buku ajar. Supriyatno (2006) menyatakan bahwa penulisan tes atau penilaian hasil belajar bagi peserta didik yang belajar dengan buku ajar pada prinsipnya tidak terlepas dari pengembangan buku ajar yang dilakukan.

\section{Daftar Pustaka}

\section{KESIMPULAN DAN SARAN}

Kesimpulan penelitian ini adalah pengembangan buku ajar Biokimia dengan model Problem Based Learningmenunjukkan persentase 89,3 dari ahli materi; 78,7 dari ahli media; 95 
132 | Diyah Ayu Widyaningrum, Pengembangan Buku Ajar Biokimiamodel ...

dari praktisi, dan 95 dari uji keterbacaan.Secara keseluruhan buku ajar Biokimia menunjukkan hasil layak digunakan. Buku ajar Biokimia dapat meningkatkan minat membaca dan hasil belajar mahasiswa pada uji keterbacaan.

Saran pada penelitian ini adalah uji coba menggunakan quosy experiment untuk mengetahui keefektifitasan pada minat membaca dan hasil belajar pesera didik. Menyampaikan produk buku ajar hasil pengembangan pada seminar skala regional bahkan nasional dengan menyampaikan hasil penerapan buku ajar dalam meningkatkan minat membaca dan hasil belajar siswa.

\section{DAFTAR RUJUKAN}

Arikunto, S. 2008. Dasar- Dasar Evaluasi Pendidikan. Jakarta: Bumi Aksara.
Gijselaers, W. H. (1996). “Connecting problembased practices with educational theory." In L.Wilkerson \& W. H. Gijselaers (Eds.), Bringing problembased learning to higher education: Theory and practice (pp. 13-21). San Francisco: Jossey-Bass.

Prastowo, A. 2012. Panduan Kreatif Membuat Bahan Ajar Inovatif: Menciptakan Metode Pembelajaran yang Menarik dan Menyenangkan. Yogyakarta: Diva Press.

Sungkono. 2009. Pengembangan dan Pemanfaatan Bahan Ajar Modul dalam Proses Pembelajaran. Majalah Ilmu Pembelajaran 5(1): 49-62.

Thiagarajan,S.,etal.1974.InstructionalDevelopment for training teacherof expectional Children. Minneapolis. Minnesota. Leadership Training Institute/ Special Education. University of Minnesota. 